\title{
OBITUARY
}

\section{ARNOLD ADRIAAN BAKE}

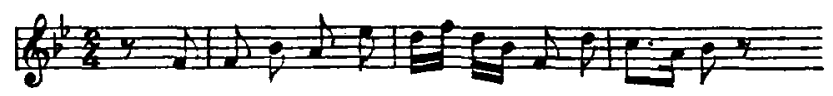

The new academic year was scarce a week old when we heard with sorrow that Dr. Arnold Bake had died on the 8th of October 1963. A week and fifteen years in the service of the School and the University, he sought with abounding energy to win-not for himself, but for his subject-a recognition long overdue : to the service of that subject, these years and all the earlier years of his remarkable career as a scholar were dedicated wholeheartedly. He was already internationally acknowledged as an authority on Indian music before his appointment as Lecturer at the School in 1948 ; and the assessment printed in The Times of 9 October 1963 was no ill-considered hyperbole: 'No other western scholar has ever rivalled Arnold Bake's profound knowledge of Indian music'.

Born in Hilversum on the 19th of May 1899, he was educated there and, from 1912 to 1918, at the Haarlem Gymnasium. If at that time he entertained any thought of becoming a professional musician, he could surely not have dreamt that his life's work would unite in one person the careers of Indologist, musician, and musicologist. There was no such profession.

Yet, in a sense, the foundations of both aspects of his later work had been prepared before he entered the University of Leiden in 1918. He studied the pianoforte in his schooldays ; from early childhood he displayed a remarkable musical memory; and of his infancy his family sometimes used to say-as families will - that ' he sang before he talked'. On the other side, his intellectual aptitude was of the type to derive most benefit from the traditional educational system of the Netherlands, the thorough, classically based grammar-school education of the Gymnasium. With unusual linguistic gifts reinforced by such a training, he intended that his university studies should equip him for a post in the language branch of Government service in the Netherlands Indies. Here was the prospect of a career both interesting and secure ; a career in an established profession in which he would undoubtedly have been successful ; a profession nevertheless which would have claimed all his working life in the exercise of half his talents. He never entered that profession. During the preliminary training, external events deflected the course of his life. An economic crisis caused the Government to reduce drastically the number of available places in the East Indies service. Uncertain now of the prospects of an official appointment, the young student faced for a time the anxiety of choice between two other possibilities: whether to seek a career in music or in academic oriental studies.

Those of us who knew him only at a later period may too easily imagine that 


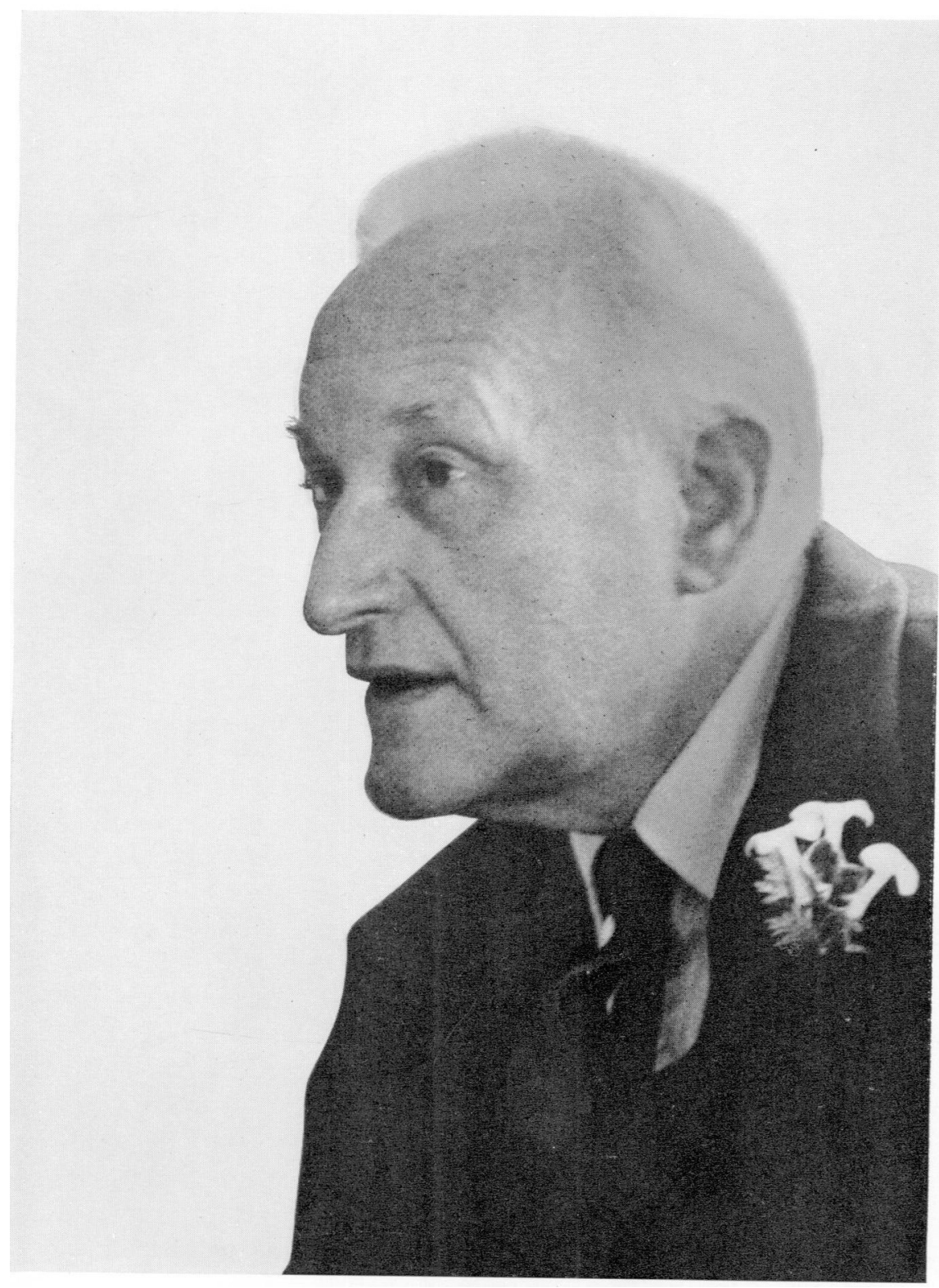

Arnold Adriafix Bake

BSOAS. XXVI[J 
there was no problem, that the answer must have been seen to be inevitable. Hardly so to the young undergraduate. But we cannot doubt that the decision which he reached-' der schwergefasste Entschluss'-was the right one : to follow the path which was the resultant of his intellectual endowments and training, a path which led him through a unique career, a career in which he found great joy and satisfaction. It was not an easy career, nevertheless. The rewards were not such as the world accounts success. There were often periods of hardship, of anxieties and ill health ; on several occasions, serious illness. Where a lesser man would have faltered, Arnold Bake's sense of vocation, his absorption in the subjects of his research, held him to his chosen course. In all his journeyings, his wife was constantly with him, sharing his happiness in the sheer interest and enjoyment of discovery, and matching his courage when times were adverse.

Government service in the Indies might well have seemed interesting and secure; without question, the career which he made for himself gave to his life a diversity and interest incomparably greater; yet we must not forget that security-a familiar and precious concept for our professional classes-was something that Arnold Bake hardly knew before his fiftieth year.

These few pages cannot hope to do even approximate justice to this most unusual life-history. The fascination of the detailed story would require, as it certainly deserves, a book of no small compass. It is not redundant, even so, to mark this point: Bake's great contribution to Indian musical studies had its root in his knowledge and appreciation of Sanskrit literature. Now, most of us, I suppose, pay little attention to those who would, if they could, trim ' unnecessary' items from vocational training in universities. Yet, how many would take it for granted that, when Javanese and Malay were the languages needed for the career envisaged, the student would proceed at once to study these languages? The Dutch authorities took a sterner view. They did not want a mere dragoman, however fluent. It was necessary, of course, to know the languages, and to know them well ; it was also necessary that a Government servant should have a proper education. Therefore, all candidates for the language service in the Indies were required to study Arabic and Sanskrit for the first three years of their training. Bake thus had the advantage of working under two of the most distinguished Orientalists of the day: Snouck Hurgronje in Arabic, and J. Ph. Vogel in Sanskrit.

In his earlier years at Leiden, Bake was already having singing lessons, finding in music that necessary refreshment for which many students may turn to sports or other activities. (He himself later said of this, with typical goodhumoured self-criticism, that he 'stole time for his music from Professor' Snouck'.) When the crisis came, he seriously considered a career as a professional singer, although Indian studies had already aroused such interest that henceforth, he determined, he would retain Sanskrit literature for his recreation. Before long, he was urged from both sides-chiefly by the distinguished conductor Schoonderbeek and by Professor Vogel-to combine both interests 
in the one profession. Recalling this more than thirty years later, he remarked that he had never had cause to regret that he followed this advice, adding (not wistfully, but rather with detached amusement) that he sometimes wondered whether he might have been a wealthier man as a concert-singer.

Bake was over six feet tall and proportionately broad; and it is almost incredible to us now to learn that, as a young man, he was rejected for military service as being 'insufficiently robust, and narrow-chested'. Perhaps because of this verdict, or perhaps merely for diversity of experience, after completing the five years' course at Leiden he chose to work for two months in the mines of Lower Silesia.

In 1923 he continued his studies, now under Professor W. Caland in the University of Utrecht, concentrating on the Sanskrit treatises dealing with the theory of music. One of these, the Sangittadarpana, formed the subject of the thesis for which he was granted the degree of Doctor of Letters in 1930. In the intervening years he undertook an unprecedented course of further training. Most earlier writers on Indian music (starting indeed from Sir William Jones himself) either made only slight contributions, or were insufficiently equipped in at least one of the three indispensables. We need not list names ; but a good Sanskritist might bring to the texts a good knowledge of musical theory, but yet miss, because Indian music had not reached him through his ears. Another, with years of residence in India, and with excellent Sanskrit, could fall short in knowledge of music. Among later students of the subject, one of the best candidly confessed discontent at his lack of competence in Sanskrit. Bake was not content to neglect any one of the essentials.

It was a great encouragement that both Vogel and Caland were keenly interested in music; and from Caland, the great authority on Vedic ritual, Bake learnt much concerning the nature and significance of the chants of the Sāmaveda. He had begun to explore the work of collectors of European folkmusic ; he had already heard authentic Indian singing in Holland ; and he met Rabindranath Tagore during one of the poet's visits to Europe. The next step was India.

Bake's first contact with this School-albeit indirect-was as early as 1925. He considered that his future wife should not be ignorant of Bengali when they arrived at Santiniketan. His fiancée thought to commence this study in Paris ; but he firmly directed her to London, to the School of Oriental Studies in Finsbury Circus. And the name of Miss Cornelia Timmers stands in our records, registered for a course in Bengali under Mr. Sutton Page in the spring and summer terms of 1925. Corrie and Arnold were married in the autumn of that year, and some weeks later set out on the first of their travels together.

The next four years were centred on Santiniketan, under the benevolence of the venerable Rabindranath. There Bake came to know many Indian musicians and scholars ; and in particular his teacher, Pandit Bhimrao Shastri, and the poet's grand-nephew, Dinendranath Tagore, won his respect and affection. The continuation of the thesis-work on the theory of Indian classical music was 
accompanied by an increasing interest in folk-music, and, concurrently, by an intensive training under an Indian master, so that in a real sense Bake can also be called an Indian musician, although I never heard him claim the title. This period may thus be said to show three of the principal themes of Bake's work combining in triple counterpoint.

This first visit of four years may be considered, in the main, as a rounding off of training - a very lengthy training, it is true, but understandably so in such a subject, and amply justified by the later eminence attained. At the same time, experience was being gained in field-research, and although there was no mechanical recording equipment, many of Tagore's songs, sung by Dinendranath, and folk-songs as occasion arose, were written down in European musical notation. At intervals, there were opportunities for interesting journeys, notably to Chamba, at Professor Vogel's request, and to visit the archaeological site of the Bagh caves in Gwalior; in the summer of 1927, when Tagore suddenly issued an invitation (or command ?) that Mr. and Mrs. Bake should accompany him as his guests to Bali and Java; and a year later, to Rajputana.

Returning to Holland in 1929, Bake saw his thesis through the press ; and after its publication and the conferment of the Doctorate degree in February 1930, he found that audiences were enthusiastic to hear lectures from him on Indian music. Undoubtedly, the quality of his singing in the illustration of his lectures was an important factor ; for, in spite of the intrinsic interest of the subject, an exotic music would hardly have had much attraction if indifferently performed. A lecture-tour was duly arranged, including a lecture in London, at which he sang some songs by Tagore--who was himself present in the audience; and in Paris he attracted the attention of Professor Sylvain Lévi, the doyen of French Indologists, who greatly admired his work, and encouraged him to pursue his research further.

At the end of the year, Bake and his wife sailed again for India, and arrived in January 1931. This time extensive plans for field-research, now under the auspices of the Kern Institute, Leiden, were to involve constant travel, by train, bus, and (when occasionally they were state-guests) by private car. There was now a phonograph to record music on wax cylinders, and equipment for motionpictures as well as still photography.

We can glance at only a few highlights in these busy and fruitful years. Notable indeed was the journey in July 1931 to Nepal, which was still to remain a closed country for another twenty years. In effect, except for those connected with the British Residency, no European could enter the country except with the personal permission-almost never given-of the Maharaja (the hereditary Prime Minister). Sylvain Lévi was one of the very few to whom this permission had been granted; and he now wrote to the Maharaja Bhim Shamsher Jang Bahadur Rana, asking that Bake should be allowed to visit the Kathmandu valley, for the purpose of scholarly research. The request was granted, grudgingly, it seems, since the permit was for a visit of twelve days only. Fortunately, the Bakes were sufficiently optimistic to go, and in the end they 
were allowed to stay for about four months. Much interesting and valuable material was recorded, among which some of the religious items were especially important: recordings of religious chants, with films of the accompanying ritualistic postures and dance-movements.

A remarkable feat was the recording, in South India in the following year, of Vedic hymns, including chanting from the Sämaveda. We may tend to underestimate this achievement now, especially since we have seen subsequently, here and there, some slight relaxation in orthodox Brahmanical rigidity; and in the last ten to fifteen years a few other scholars have obtained further Vedic recordings. Yet, even to-day, such field-research can all too easily be frustrated by traditionalists who oppose disinterested scholarship with bitter hostility. In 1932, when Bake proposed to record Sämaveda singing, and in the orthodox South, no one would have supposed that he had any chance of success : yet he succeeded. About the preliminary negotiations he told me very little; but we can be sure that the Brahmans were impressed by the warmth and charm of his personality, and that they consented to sing for him because they recognized intellectual integrity which ensured that their sacred music would be used for no trivial purpose.

Eight or nine months before this, Bake's researches in India might well have been concluded abruptly. The international economic depression compelled the Trustees of the Kern Institute to inform him that they could give no further financial support. In spite of this, he refused to abandon the work : rather than this, he would himself earn the money needed. Accordingly, he continued his journeyings in India and Ceylon, giving a series of lectures and concerts, as professional engagements, singing European and Indian musie, and discoursing on both, in schools and colleges, in public concerts and in private recitals. These engagements, at an average of about six or seven a month, could certainly not be expected to provide a sumptuous living. But the fees thus earned made it possible for the research to continue ; and after more than two years without other financial assistance, Bake and his wife returned to Europe in late spring of 1934.

Travelling was resumed only a year and a half later, for a lecture-tour (November 1935 to May 1936) in the other hemisphere. The plan of returning by circumnavigation had to be given up ; and it must have been most tantalizing to reach as far west as Honolulu-roughly as close to the International Date Line as Calcutta is to Bombay. It was possible, however, to include a brief visit to Canada, to meet and discuss musicology with one of the leading authorities on the folk-music of the American Indians, Marius Barbeau. How many lectures were delivered on this tour I do not know ; but the list included at least eleven universities: Yale, Columbia, Pennsylvania; Chicago and Hawaii; Berkeley, and a progression eastwards ending with North Carolina.

Except for the seven months of this tour, most of the time between 1934 and 1937 was spent in London : a quiet interlude after India, but by no means an idle one (meno mosso, ma non troppo tratto), during which Bake had numerous 
and profitable discussions with A. H. Fox Strangways on Indian music, and also took the opportunity of keeping his European singing in good trim, studying now under Reinhold von Wahrlich.

In 1937 Bake was given a new opportunity for field-research in India, and in a manner which at that period must have seemed to him almost miraculous. Those of us who have seen at first-hand the steady expansion since 1946 of the range of academic study in so many aspects of non-European civilizations can accept the idea of a subject such as Bake's as something not in the least surprising. We are indeed aware that the theory, history, and practice of Indian music is in many ways more difficult and requires a more unusual combination of abilities than many of our other ' exotic' subjects. We cannot expect that the future will bring us, at the best, more than a handful of scholars who can approach the breadth and thoroughness of Bake's knowledge in this field. None the less, even those who were already University teachers in 1937 will doubtless recall only by the exercise of positive effort (those of us who were not can but try out our powers of imagination, probably underestimating when we think we exaggerate) the extent to which a specialization in Indian music would have seemed then to be exotic, and far outside the limits of what might reasonably be studied and taught in a University.

This branch of Indological studies is therefore all the more indebted to the far-sightedness of the Principal and Fellows of Brasenose College, Oxford, when in 1937 they made use of an endowment, from the late Mr. H. N. Spalding, to elect Arnold Bake to a Senior Research Fellowship of the College.

The original intention appears to have been that this Fellowship should be held for four years : three to be spent in the collection of further musicological materials in India and Ceylon, and the fourth year in residence in Oxford, while writing up the results of the research. This was, of course, prevented by the outbreak of the second World War. There was no possibility of returning to England in 1940 or in 1941 ; and since at that time no particular purpose would have been served by returning, it seemed in every way best to remain in India and to continue, as far as conditions allowed, the musicological research. Most gratifyingly, Brasenose College extended the tenure of the Fellowship until 1944 ; and in spite of restrictions now on travel, it was possible for the work to go forward with only brief intermissions. Once, indeed, there was a delay of several months in the transfer of the stipend-money to India-a delay for which the College was in no way to blame ; and for mere subsistence Bake had to find paid employment, first, in late 1940, as Music Adviser to All-India Radio in Delhi ; and then as Director of European Music at the Calcutta broadcasting station. But he had scarcely taken up the latter appointment when, in the early summer of 1941, the delayed stipend at last penetrated the barriers of bureaucracy.

From 1937 to 1939, however, the Bakes travelled and worked, photographing and recording, studying dance and all the manifold aspects of society at all levels into which music entered, from Ceylon and South India to the remote 
Tibetan monasteries of Ladakh. There can be few others-European or Indianwho have acquired such an intimate knowledge of Indian life, and over so extensive a range of territory ; knowing the dwellings of the wealthy ; but more often among the villagers. This was a journey similar to their second visit, but with all the profit of experience then gained. For the first time they now had their own means of transport, a station-wagon ; and improved equipment for sound-recording. The last was indeed superior to the phonograph, although as temperamental as a prima donna. The sound-track was traced on film, a saving in weight which was no absolute advantage, since power was supplied by a cumbersome motor (also sulky), the noise of which could be excluded from the recording only with difficulty and the use of a very long connecting cable. Ultimately a complete breakdown of the instrument made it necessary to send it for repair to the maker, in Germany. And it was repaired; and it was already on the sea voyage back to India at the beginning of September 1939. War forced the ship to Massawa in Eritrea; and Bake never saw the recordingmachine again.

In a letter to Brasenose College a few months later, Bake wrote that he had meanwhile been using a Swiss machine, hired at $£ 12$ a month ; but, as he said, it seemed more economical to buy it outright, at a price of $£ 60$. This alternative machine made its recordings on dises-much more bulky than the films of the other, about six times heavier, and at least ten times more costly. 'Still,' he concluded, 'the very fact that they enable me to carry on with the work is worth all the disadvantages.' Characteristically, he did not add that all this additional expenditure was more than he could afford; but I have little doubt that this was so, and that he was cheerfully prepared if necessary to accept a severely reduced standard of living in order to continue the work.

Most of the time between 1941 and the end of the war was spent in or near Calcutta. Naturally, unrestricted travel in the countryside was now no longer possible ; but we may doubt whether an extension of the survey to include other regions would have done more than round out in a few minor aspects the remarkably comprehensive view which the earlier years had already provided of the religious and folk-music of the sub-continent. Bake turned the circumstance to advantage, by applying himself now to a more profound study of the music of Bengal, and its religious music in particular. The most important aspect here was indubitably his study of the kirtan, a term best known as the name used by the Bengal Vaiṣnavas for their worship in song of Krṣna (although the term is not confined to this sect). Chiefly during the past four centuries, this type of composition (performed in worship by a solo singer and chorus, without instrumental accompaniment other than drum and cymbals) has been developed into an intricate and distinctive musical art ; and the great musical interest of this art had certainly not escaped Bake's attention during his earlier visits.

It would be foolhardy to suggest, even implicitly, that there is anything here even approaching the incomparable art of men such as Dante or J. S. Bach. Yet religious art of high quality, although it be far short of these, not infrequently 
shares with them in some degree an aesthetic quality which does not require for its appreciation that the hearer should share the religious beliefs which inspired the art. A denial of this relative independence (as a Sanskrit philosopher might argue) is rebutted by everyday experience, and trips up on the fact that the denial logically implies that almost all religious art should be incomprehensible to almost everyone : anubhavavirodhāt, svakiyamatānanusārijanaviracitakāovya-

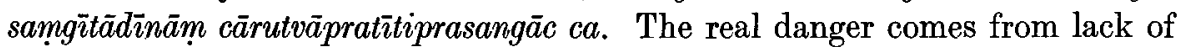
knowledge of the religion and the cultural context-but this is too obvious to require illustration. But it must at least be said, in order to make it clear that not even partial support is offered to our contemporary heretics: those who believe that the arts of remote times and cultures can be assessed, out of context, ' in and for themselves '. Bake's extensive knowledge of modern India and of the ancient civilization made him immune to such superficial ideas.

A more important reason for elaborating this point is that, among the sectarian worshippers of Krṣna, some at least have cultivated intolerably an effeminacy of attitude which, even if supported in dogma, is not thereby rendered any the less disagreeable. In its more extreme manifestations, the religion may, to outsiders, seem to consist mostly of a sort of sybaritic spiritual sensuality, a sentimentalist sensuousness of the emotions: such surfeit of butter and honey may be too cloying for some of us. Granted, this is not the whole of the picture ; but it is an aspect which to the European reader almost inevitably appears predominant, if only because of its distastefulness. I say this not in a spirit of polemic, but from necessity : it would be unforgivable if reticence on my part were to leave room for unjustified conjecture. Explicitly, the characteristic flaccidity of this religion stands in utter contrast to Arnold Bake's own character : sentimentality he despised, effeminacy was entirely foreign to his nature.

Moreover, from time to time one or two of our own compatriots, as we hear, are converted to certain Hindu or Buddhist religious beliefs, usually miscalled by them 'philosophy': seekers of salvation who seldom achieve press publicity unless they are already known to the public. Such men may then have won distinction in their own professions; yet how few give any thought to the fact that in Indological studies they are mere amateurs, and scarcely even beginners?Maar ' ik behoef mij geenszins te beroepen op [zulk een] bijgeloof, . . . noch op dweepers, zoo hoog en fijn van lucht, dat het gezond verstand er niet in kan ademen '. Bake was indeed very deeply interested in Indian religions, and had an extensive knowledge of many types of Hinduism beside Vaiṣnavism, but with the advantages of being a professional, and of an affection for India based on long experience and study. With inborn courtesy, he respected the religious views of his Indian friends, and could often attain a sympathetic understanding of their beliefs, gaining thereby respect and a warmth of friendship such as few of our Western neo-' Vedāntins' are likely to win among Hindus. Being a scholar, not a convert, Bake was hardly the man to see profit in exploring the tenuous atmosphere of mysticism. 
Thus much, then, by way of clarification, in order to avert possible misunderstandings.

On earlier occasions Bake had worked on the kivtan of Bengal as an external observer. To be present as a listener was the limit of privilege to be expected for a non-Hindu, and even, perhaps, for a Hindu from a distant part of India. Yet in 1941 Bake was accepted as a pupil, to learn the art of kirtan as a performer, and under no insignificant teacher, but an elderly and revered master of the art. (I do not know his name : a man so highly respected was invariably addressed and referred to only by his honorific title.) It is almost impossible to overestimate the value of direct study of music through one's own performance ; and Bake, a musician of many years' experience, threaded the labyrinth of the melodic and rhythmic patterns of kīrtan-singing with competence and skill which, as we know, won high commendation from his teacher. Indeed, something rather more, since before very long there was added to this commendation an invitation to sing in the chorus at kirtan-worship. And still more was to come.

A year or two later the old teacher, while on pilgrimage to the famous place sacred to Kṛșa, Brindavan near Mathura, remarked to his pupil that enough, surely, had been learnt by now ; that, with the additional practice as a member of the chorus, the necessary experience had been acquired ; it was time, then, to take the solo part in the kĩrtan about to be sung. Bake was thus given the unprecedented honour, and at Brindavan, of leading the singing in the worship of Kṛ̣na : an honour, indeed, yet also a considerable ordeal, and at very short notice. We can only guess whether he awaited the commencement with nervousness or with complete calm. But certainly all went well, and the old gentleman his teacher was thoroughly satisfied with the manner in which his pupil successfully carried the solo as kirtan-leader through the whole performance of two hours or more.

It would be rhetoric out of place to assert that this was the summit and climax of Bake's career. He must of course have been gratified that the arduous training and practice had led to this success; and in later years (although by then very few persons had an inkling of the facts) he did consider his knowledge of Bengal kirtan an important item among his scholarly assets. Still, I feel sure that he would have laughed at any suggestion that the solo performance at Brindavan was one of the greatest of his achievements. And yet this was an astounding virtuosity, an achievement quite extraordinary. I say it was unique, and challenge any contradiction : the like had never before been accomplished by a European; and it is hard to believe that another European will ever in the future be able even to approximate this accomplishment.

From July 1944, when the strictures of the economy prevented further renewal of the Oxford Fellowship, the Bakes were forced to fend, as formerly in 1932, by finding fee-paying engagements: but with a difference. Then, they could have returned earlier to Europe if they had so chosen; now, it was even futile to guess how long the war might detain them in India. Now, too, harsher economic conditions compelled the acceptance of more engagements, when these 
could be obtained. A period of few engagements meant, quite simply, a period of hardship. When her husband sang European songs at concerts and recitals, Mrs. Bake, as she regularly did, acted as his accompanist at the piano. As and when possible, lectures were given in schools; and classes could sometimes be provided privately, in European music from the rudiments to more advanced levels. During this time, I believe, the occupation which gave Bake most pleasure was the teaching of singing; but I suspect that pupils were too few to make this a very profitable employment in itself. In spite of everything, Bake could not be expected to abandon completely his interests in research. He continued to go for study under his kĩrtan-master, even if less frequently than had been possible before ; and this study did not cease until he left India. Nor could other aspects of research cease entirely. India perpetually presented to his eyes and ears her kaleidoscope of sights and sounds (not all of the latter, indeed, being musical) : a growing collection of images to be stored in a retentive memory-tesserae to fit into his already remarkable mosaic picture of the vast sub-continent.

August 1945 brought nothing more than a prospect of return to Europe : the actuality was still to be delayed for almost another year and a half, until the very end of 1946. A year more, and in the early days of $1948 \mathrm{I}$ first heard word from the Director of the School of a Dutch Sanskritist who had succeeded in obtaining recordings from the Vedas as recited by orthodox Brahmans. At that time I had no information about the many long years of the earlier history, and I remember picturing to myself (although why, I do not know) a promising young scholar who had presumably gone to India shortly after the end of the second World War, to collect material in the field in connexion with his researchpossibly his first postgraduate work. In March of the same year, Professor H. W. Bailey invited me to hear a talk on Indian music ; and only then, when in Queens' College, Cambridge, I met Dr. Arnold Bake for the first time, did I realize that this was the scholar of whom the Director had spoken : and not a youth at the threshold of his career, but a man in the prime of life and an established scholar.

The occasion was informal but memorable. Professor Bailey had brought together in his rooms an audience of colleagues and students, a dozen or so in all. Bake, with his great height and athletic bearing, and a calm assurance of manner, gave an immediate impression of dignity and authority, without trace of pomposity. Rather, there was a touch of diffidence, just concealed ; and even at a first meeting, one could sense that kindliness and sincerity of character which we his colleagues afterwards came to know so well. When his listeners were settled in chairs around the room, Bake sat down cross-legged on the floor, and spoke on music in relation to religion in India. I dare not assert that never before in Cambridge had a lecturer sat thus on the floor while addressing an audience. Still, we may safely say it is unusual, and that the idea would previously have seemed to most of us to be slightly comic, perhaps, and unquestionably eccentric. On this occasion it seemed entirely natural. Bake was so obviously at ease and completely without self-consciousness that his audience 
was not even surprised. The substance of his talk was undoubtedly worth hearing for its own sake; but it was the songs he sang to illustrate each successive topic-yet not the songs, but rather, his singing of them - which cast the spell.

In the summer term of 1948 we had the opportunity of hearing him give a public course of lecture-recitals at the School ; for which pleasure we owed much to the good offices of the late Sir Cecil Kisch, then Treasurer of the School, who had known Bake since 1934. In the audience was the nephew of the Maharaja Bhim Shamsher: His Excellency the Nepalese Ambassador, General (now Field-Marshal) Kaisar Shamsher Jang Bahadur Rana, who was greatly interested in Bake's work, and recalled with much pleasure their meeting in Kathmandu in 1931.

Bake joined the School in October 1948 as Lecturer in Sanskrit and Indian Music, and a year later was appointed to the Readership in Sanskrit in the University of London. During the remainder of his career, an increasing number of students came to learn from him something of the fascination of his subject. It was an especial gratification to him to realize that, though many might still think the subject remote, there were some among his students who would in due course carry the succession in this branch of scholarship, the more so since a break in the succession, where one man had been responsible for so much of the pioneering work, would have been an irretrievable disaster. Even while mourning the man, and grieving at the vanished knowledge he alone possessed, we can yet feel thankful that much has been taught to others, and that his work will continue to bear fruit.

Bake's appointment to a university teaching post did not mean that his own researches in the field were at an end. The session 1955-56 was spent in Nepal and India on overseas research leave; and a similar visit had in fact been planned for 1961 or 1962 . But, sadly, this further visit was prevented by ill health.

In 1955-56 I had the opportunity (being one of several teachers from the School who at that period visited Nepal for study and research) of seeing something of Bake's field-work in progress. He and his wife had arrived about two months before us, and it was chiefly through their efforts that a fairly new house was, after much searching, found and rented, to provide reasonable and economical living accommodation for any members of the School who were in Kathmandu at a given time.

Not only was Bake remembered in Kathmandu by very many people who had met him in 1931, but his own astonishing memory (as Mr. T. W. Clark told us in his funeral oration) enabled him to recognize and unhesitatingly address by name an incredible number of these same persons, after almost a quarter of a century, so that his return to Kathmandu was in the nature of 'a triumphal procession'. There can be no doubt that the goodwill he had earned became an asset for all of us. Certainly my own work on Buddhist manuscripts was very much indebted to the generous spirit in which Field-Marshal Kaisar granted me free access to his own private library, with permission to take microfilm copies 
of any of the items in his remarkable collection of manuscripts. The FieldMarshal, being himself a scholar, would, I am sure, have granted such facilities simply for the sake of academic research ; but I am also sure that my reception was all the more cordial because of the high esteem in which he held Bake-an esteem which was, so to speak, reflected upon Bake's colleagues.

Bake set out to make during this period a thoroughly representative compilation of the vocal and instrumental music of the Nepal valley, this exceptional area whose inherited culture has remained, until the past few years, almost untouched by outside influences, and where, in contrast to India, the tradition of Buddhism has survived together with Hinduism. It is fortunate that this study was not postponed longer, since even in 1956 the unavoidable ' modernization' was obviously accelerating, at least in the central valley around Kathmandu. It is possible that the music, more than some other aspects of the culture, may have the chance to survive longer, being as it is an aspect outside the benevolence of teams of Europeans and Americans sent by the United Nations Organization. Nevertheless, even the music is threatened in Kathmandu, not by the West, but by India. This threat, of course, does not come from the real music of India, but from that wretched hybrid vulgarization, the Indian 'film-song' which Bake so detested, as any musician naturally would.

Throughout this year, Bake was frequently working under the handicap of ill health ; and a more serious illness necessitated a period of medical treatment in Calcutta and several weeks of convalescence. Even so, his energy and enthusiasm were such that he brought back to London not only an unrivalled collection of music, but also visual illustrations consisting of some 3,000 feet of ciné-film and several hundreds of still photographs. The recorded music comes to a total of approximately $\mathbf{5 0}$ hours, and includes examples of almost every conceivable variety of the music of the Gorkhas and the Newars, the two main populationgroups in the Valley : Hindu and Buddhist chants and hymns of praise ; music of the sacred dances ; songs for religious festivals ; peasant songs for work and play, for birth, for marriage, for death ; ballads of the itinerant minstrels (as cacophonous, these last, as anything I remember hearing) ; and, in addition to all these, songs of Tibetans, and of numerous ethnic groups from outside the Valley. It was good fortune that Bake was in Kathmandu at the time of the coronation of King Mahendra on 2 May 1956. This was in itself a traditional Hindu ceremony of great intrinsic importance ; and for the occasion there came to Kathmandu from distant parts of. Nepal men and women from whom Bake obtained recordings of songs which, in other circumstances, could not have been collected without walking hundreds of miles through the mountains.

Much of this rich store of music still awaits more thorough examination; and we are fortunate indeed that Bake has made it accessible, and that it will still be preserved on tapes in London, and available for study even if some of the items should meanwhile become extinct in Nepal itself.

Bake's regular introductory lectures on Indian music unfailingly attracted students not only from within the School but also from the colleges of music, and 
more advanced students, if they knew enough of the language, would then read under his guidance some of the technical literature in Sanskrit on classical Indian music. Only a very few could proceed to the next stage, and carry the study still further in India ; but among these few is one of Bake's earliest pupils at the School, Dr. J. R. Marr, who is now Lecturer in Tamil and in Indian Music (and who is also a good Sanskritist). Bake himself always emphasized the necessity of a good Indological foundation, in Sanskrit, or, for South Indian music, in Tamil. One of the few things which made him seriously angry was a publication on Indian music by an author inadequately equipped : for seldom could such an author resist deductions which, even if formally valid in logic, took as a premise a misunderstood and often quite elementary Sanskrit passage.

The fact that in his later years at the School a number of postgraduate students came to work under his supervision in the preparation of theses on musicological subjects for the degree of $\mathrm{Ph}$.D. was especially gratifying to him. It was, one might say, something of a triumph when the University, through the Board of Studies in Music, in due course agreed to accept thesis-subjects in branches of musicology outside the European tradition. When, ultimately, he himself became a member of the Board of Studies in Music in January 1961, it meant much to him that his subject had in this way won definite academic recognition within the University. At quite a different level, he also had the satisfaction of seeing recently the adoption by the University of his proposals for the inclusion of a paper on the history and principles of Indian music among the options available to candidates for B.A. Honours degrees in modern Indian languages, and a similar paper together with a second on specified Sanskrit texts for the B.A. Honours degree in Sanskrit. And, to the best of my knowledge, no other Honours degree in language and literature, either in London or in any other of our universities, has as yet been equally enterprising.

During Bake's fifteen years as a member of the teaching staff of this School, interest in musicology has developed considerably in other Departments also. In the Department of Africa, the Reverend A. M. Jones was appointed to a Lectureship specifically in African Musical Studies. In the case of a number of other teachers who are primarily concerned with language and literature, an interest in the musical aspects of the culture under study must undoubtedly have been stimulated and encouraged by the mere presence in the School of a man such as Bake. Increasingly during his later years, younger colleagues naturally looked to him for guidance in the music of very different civilizations, tending to form a musicological group with Bake as their focusing point.

Outside the School, Bake's authoritative standing in musicology and closely related subjects was internationally recognized. He was a Corresponding Member of the Royal Netherlands Academy of Sciences (De Koninklijke Akademie van Wetenschappen). He also served on many important committees, national and international: he was a member of the Executive Board of the International Folk Music Council; a founder member of the International Society for Folk Narrative Research ; a member of the Council of the Folk-lore 
Society. He served on the Council of the Internationale Gesellschaft für Musikwissenschaft; and was one of the original members of the Committee for Ethnomusicology of the Royal Anthropological Institute, and was appointed Chairman of that Committee early in 1963. It is appropriate to direct the attention of the reader particularly to the subject last mentioned; for it is obvious that Bake was very much aware from the time of his earliest field-work that music in societies less sophisticated than our own is seldom an ornament, but is woven warp and weft into the fabric of the society. I do not mean to imply that the study and classification of the patterns painted on the cloth is in itself an unworthy scientific preoccupation; but a study which accepts this as a limit accepts also by implication a circumscribed understanding. It always seems a pity when a scholar refuses of his own volition to admit that his scope could with advantage be extended. Bake, as an anthropologist engaged in the study of a cultural manifestation which interpenetrates so many aspects of social activity, was not only better placed, but was virtually compelled to attain a genuine comprehension of many types of Indian societies to an extent far beyond the capacity of those who restrict their examination to the superficies.

Bake combined the qualities of a scholar and of an artist in a balance which is very rarely found. In later years, perhaps, he tended more to consider himself by profession a musicologist with India as his specialization, while remaining for his own pleasure a musician whose delight was in Western music. In the former capacity, he studied with intense interest much ' music' which seemed to me not only primitive, but intensely ugly-sounds which could have little claim to the name of art. The reader, however, will make due allowance here for my own cultural prejudices, and will understand that absence of aesthetic appreciation was sometimes (certainly not always) due only to insufficient experience. I was in fact driven to this conclusion myself (indirectly, it is true) by the Indian harmonium, an object Bake detested with a venomous hatred. The word may cause many Western readers to think of a type of pseudo-organ with five octaves, roughly of the size of an upright or miniature piano, and blown by treadles. But the usual form in India is a little box, with a three-octave keyboard, a few inches above the floor, played by one hand (the other being needed to work the bellows), and with a tone even more unpleasant than that of its European ancestor. Why the Indians have manufactured huge numbers of these pernicious things for use in their own music is still mysterious. Since the tuning is in equal temperament-if the listener is sufficiently optimistic-the fearsome effect on Indian modes with their unequal intervals needs no further comment.

Equipped by nature with an excellent voice, and thoroughly trained as a singer, Bake achieved a standard of performance which many professional concert-singers might envy. He could take high tenor notes without hint of falsetto ; and one of the most technically impressive performances I heard from him was the basso profundissimo of a Tibetan Buddhist chant. His mastery of Indian types of voice-production, so different from that of his original European 
training, showed a quite exceptional virtuosity. The same ability to hear and to imitate subtle acoustic distinctions also gave to his spoken English an unusual phonetic excellence ; and, in lighter vein, also enabled him to produce uncannily lifelike imitations of the voices of farmyard animals, by which he unfailingly evoked the amazement and delight of children.

Few of his colleagues at the School knew much about Bake's earlier career, of which he seldom spoke-not because he was by nature reticent, but rather because he was usually too intent upon current activities to spend much time in conversational reminiscence of the past. His life-history was indeed extraordinary ; nor would anyone deny that he was a most unusual man. Yet in his character he was not in the least eccentric.

The last five years were overshadowed by tragic suffering. In the summer of 1958, he was seriously injured in a street accident in Leiden. Before many months, he was back at the School and, except when recurring periods of illness made it impossible, he continued his work with great courage and determination, persisting to walk although unable to dispense with the use of sticks at least. But a broken thigh never healed completely, and although his cheerfulness often made it hard for an observer to believe, he was seldom if ever free from pain throughout all of these last years.

A certain amount of research carried out in universities produces results which are seen to have a practical application, to be useful in a way which appeals to 'ordinary men and politicians'. It is easy enough to understand how attitudes are influenced by this fact, and how our universities are thus more than ever before threatened, directly and in more subtle ways, by the pressure of the profanum uolgus. Bake's work was altogether without 'practical utility' in this sense; but it had that quality which is of the greatest importance in a university. Unless we can awaken in our pupils some sense of enchantment, of delight, whether in aesthetic appreciation or in the excitement of purely intellectual understanding or fresh discovery, then we have failed in one of our most vital functions as university teachers. We should like to feel that we could apply to ourselves, metaphorically, the words of Horace's ode. But Arnold, surely, could have said, without metaphor at all :

\section{carmina non prius \\ audita Musarum sacerdos uirginibus puerisque canto.}

Beside a melody in one of the sketch-books, Beethoven wrote the annotation, 'Süsser Ruhegesang oder Friedensgesang'. So indeed it is ; and yet how much more, when it appears in the final perfection of his last string quartet. The vigorous energy of the scherzo, gradually fading in volume without loss of momentum, insists and again insists on $\mathrm{F}$ major, ending with ten repetitions of the tonic triad, softer and softer, until the outburst at full power on the last chord ; and after a pause, there comes the single sustained, quiet $F$ of the viola, and then the entry of the second violin, with A flat. (Surely we are about to hear 
a slow movement in $\mathrm{F}$ minor ?) But now the first violin gently works a miracle, and the violoncello adds the root, to complete this awe-inspiring transformation into a swelling chord of D flat major. And, softly, Beethoven's theme of rest and peace is revealed to us, in singing music of profound, unearthly beauty, a music not of sorrow, but of a divine compassion :

Lento assai, cantante e tranquillo
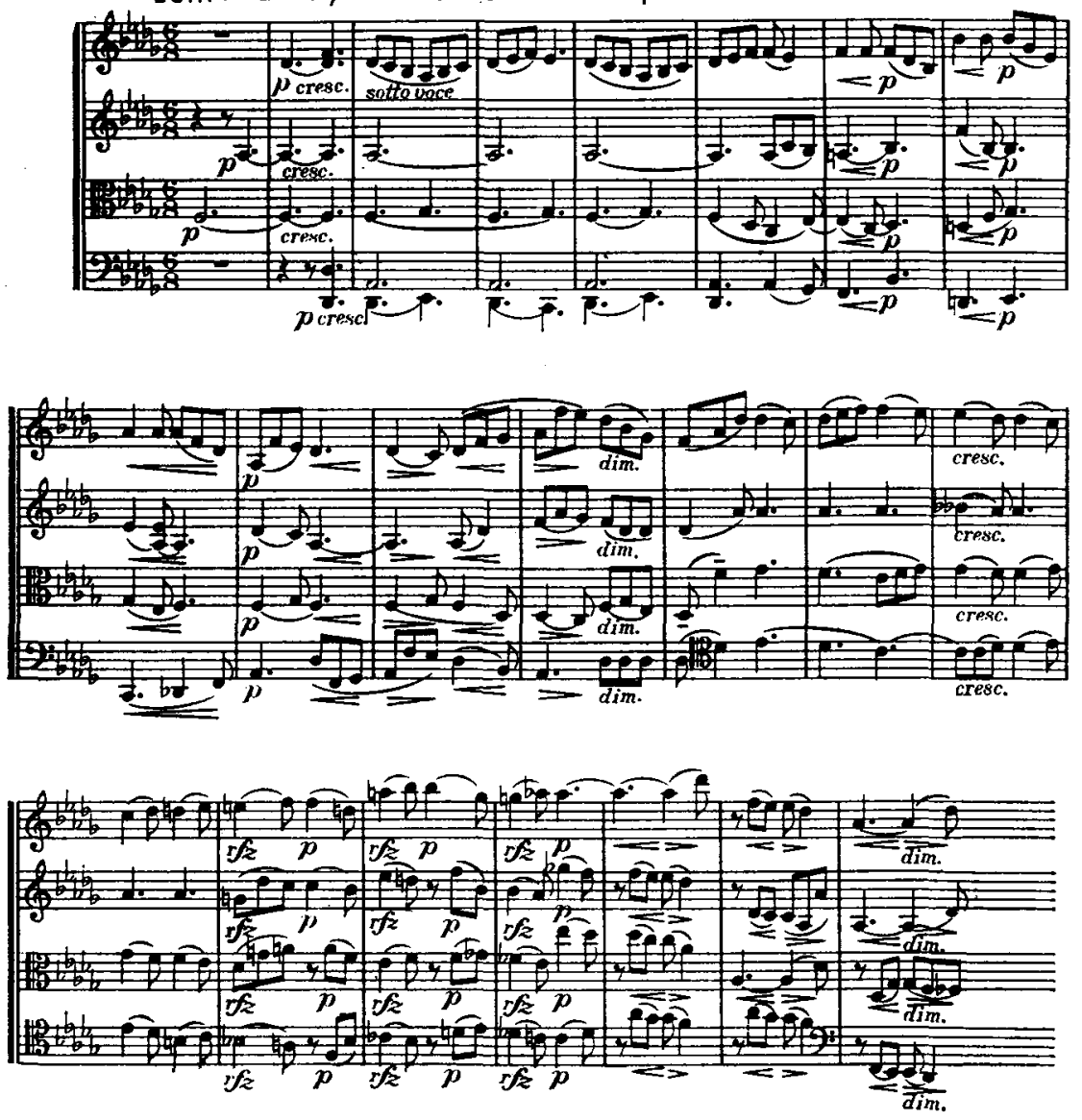

Arnold Bake, scholar and musician, will be remembered for his outstanding contribution to Indian musicological scholarship. It hardly needs saying that such scholarship would not have been possible without his thorough training in European music; and his friends are aware how much he loved the great classical music of our own civilization, and how intimately he knew it. When his family, and we who were his friends and colleagues, met together in the chapel on the 11th of October, it was fitting that our last farewell to him was to the accompaniment of this most sublime music.

Cantante, tranquillo: what better requiem for such a man? 